\title{
Mycosis Fungoides and Sezary Syndrome T4 TNM Finding v7
}

National Cancer Institute

\section{Source}

National Cancer Institute. Mycosis Fungoides and Sezary Syndrome T4 TNM Finding v7. NCl Thesaurus. Code C88235.

Confluence of erythema covering $80 \%$ or more of body surface area. (from AJCC 7th Ed.) 